Proceeding Paper

\title{
Developing an Electrochemical Biosensor for the Detection of Hemagglutinin Protein of Influenza A Virus Subtype H1N1 in Artificial Saliva ${ }^{\dagger}$
}

Carlos Torres-Méndez ${ }^{1, *}$, Jayendra Ellamathy ${ }^{1}$, Maria Ines Mascarenhas ${ }^{2}$, Yifan Liu ${ }^{1}$, Georgia-Vasiliki Gkountana ${ }^{2, *}$, Patrizia Kühne ${ }^{2}$, Javier Sebastián ${ }^{1}$, Ivana Jovanovic ${ }^{2}$, David Bern ${ }^{1}$, Sharmilee Nandi ${ }^{2}$, Maike Lüftner ${ }^{2}$, Viktoria Langwallner ${ }^{1}$, Maria Lysandrou ${ }^{2}$, Sam Taylor ${ }^{1}$, Klara Martinovic ${ }^{2}$, Abdul-Raouf Atif ${ }^{1}$, Ehsan Manouchehri Doulabi ${ }^{2}{ }^{\mathbb{D}}$, Masood Kamali-Moghaddam ${ }^{2, *}$ and Gemma Mestres ${ }^{1, *}$

\section{check for}

updates

Citation: Torres-Méndez, C.;

Ellamathy, J.; Mascarenhas, M.I.; Liu,

Y.; Gkountana, G.-V.; Kühne, P.;

Sebastián, J.; Jovanovic, I.; Bern, D.;

Nandi, S.; et al. Developing an

Electrochemical Biosensor for the

Detection of Hemagglutinin Protein

of Influenza A Virus Subtype H1N1

in Artificial Saliva. Chem. Proc. 2021,

5, 80. https://doi.org/10.3390/

CSAC2021-10477

Academic Editor: Maria Emília de

Sousa

Published: 30 June 2021

Publisher's Note: MDPI stays neutral with regard to jurisdictional claims in published maps and institutional affiliations.

Copyright: (C) 2021 by the authors. Licensee MDPI, Basel, Switzerland. This article is an open access article distributed under the terms and conditions of the Creative Commons Attribution (CC BY) license (https:// creativecommons.org/licenses/by/ $4.0 /)$.
1 Division of Biomedical Engineering, Department of Materials Science and Engineering, Uppsala University, Box 35, 75103 Uppsala, Sweden; jayendra.ellamathy.0855@student.uu.se (J.E.); yifan.liu.5161@student.uu.se (Y.L.); javierenrique.sebastianalonso.8237@student.uu.se (J.S.); david.bern.5596@student.uu.se (D.B.); Viktoria.Langwallner.2522@student.uu.se (V.L.); samtamlyn.taylor.3541@student.uu.se (S.T.); abdul-raouf.atif@angstrom.uu.se (A.-R.A.)

2 Genetics and Pathology, Science for Life Laboratory, Department of Immunology, Uppsala University, 75108 Uppsala, Sweden; mariaines.berrojoromeyromascarenhas.2772@student.uu.se (M.I.M.); patrizia.kuhne.3958@student.uu.se (P.K.); ivana.jovanovic.1181@student.uu.se (I.J.); sharmilee.nandi.8806@student.uu.se (S.N.); Maike.Luftner.8985@student.uu.se (M.L.); maria.lysandrou.6833@student.uu.se (M.L.); klara.martinovic.2708@student.uu.se (K.M.); ehsan.manouchehri@igp.uu.se (E.M.D.)

* Correspondence: carlosenrique.torresmendez.5581@student.uu.se (C.T.-M.); georgiavasiliki.gkountana.3705@student.uu.se (G.-V.G.); masood.kamali@igp.uu.se (M.K.-M.); gemma.mestres@angstrom.uu.se (G.M.)

+ Presented at the 1st International Electronic Conference on Chemical Sensors and Analytical Chemistry, 1-15 July 2021; Available online: https:/ / csac2021.sciforum.net/.

Abstract: Influenza A virus belongs to the Orthomyxoviridae family and, to date, is one of the most important pathogens causing acute respiratory infections, such as the recent pandemic of 2009. Hemagglutinin (HA) is one of the surface proteins of the virus that allow it to interact with cellular molecules. Due to the fact that it is the most abundant protein in the virus capsule, it is the best target in the detection of the Influenza A H1N1 virus through biosensing devices. Our aim is to develop an electrochemical biosensor to detect $\mathrm{H} 1$ by modifying carbon screen-printed electrodes (CSPE) with gold nanoparticles and to add further functionalization with monoclonal antibodies that are specific to this protein. The electrodes were characterized by the means of cyclic voltammetry, differential pulse voltammetry and electrochemical impedance spectroscopy. Our preliminary results suggest that the selected monoclonal antibodies have acceptable affinity and bind effectively to the $\mathrm{H} 1$ protein and that the electrodes have a wide potential window in the presence of $\left[\mathrm{Fe}(\mathrm{CN})_{6}\right]^{3-/ 4-}$. In the future, we will continue to develop this biosensor in hope that it will be commercialized and be common in medical procedures during flu seasons and future influenza pandemics.

Keywords: influenza virus; voltammetry; screen-printed electrodes; hemagglutinin/HA protein; thiol chemistry

\section{Introduction}

In 2009, a novel H1N1 influenza A virus caused a pandemic leading to the death of $151,700-575,400$ people worldwide according to the estimates of the Centers for Disease Control and Prevention (CDC) of the United States [1,2]. H1N1 influenza is a subtype of influenza A virus that was previously detected in swine, which causes upper and, in some cases, lower respiratory tract infections in its host [1]. Influenza A virus causes one of the most common respiratory diseases globally, seasonal flu, and together with Influenza B, C, 
and D, is a part of the Orthomyxoviridae virus family. Moreover, influenza A virus belongs to the single-stranded RNA viruses. It has a segmented genome that encodes several viral proteins that are important for the pathogenesis of the virus [3,4]. Two of these proteins are important for detecting the virus in human specimens; these are hemagglutinin (HA) and neuraminidase (NA), which are the surface proteins of the virus involved in host invasion [5]. HA is the major protein of $\mathrm{H} 1 \mathrm{~N} 1$ and it is the protein with which the virus binds to the host's cells and invades them, while NA helps in the viral spreading from cell to cell [5].

So far, most of the detection methods for the influenza A virus are characterized by a long detection time, expensive instruments and reagents, and the need for trained technicians, thus creating an inconvenience for both the patients and the healthcare workers [1,6]. The development of sensitive and rapid detection methods, such as biosensors, is now the focus of many research groups and could be a great solution to the aforementioned problem. A lot of different biorecognition elements can be used for the detection of an analyte. However, antibodies seem to be the most widely used type among these elements.

Antibodies are specialized, Y-shaped proteins that identify pathogens by selectively binding to their membranes [7]. Due to their high specificity and sensitivity, antibodies are ideal biorecognition elements for biosensors [8]. Other biorecognition elements commonly used in biosensors include enzymes, nucleic acids, aptamers and molecular-imprinted polymers [9]. The focus of this paper is the development of an electrochemical antibodybased biosensor for the detection of the influenza A surface protein H1.

\section{Materials and Methods}

\subsection{Reagents and Materials}

HA H1N1 protein, mouse monoclonal antibodies (mAbs) and rabbit polyclonal antibodies (pAb) were purchased from Sinobiological (Frankfurt, Germany). Secondary goat anti-Rabbit IgG antibodies (Alexa Fluor 568) were purchased from Thermo Fisher (Waltham, MA, USA). Chloroauric acid $\left(\mathrm{HAuCl}_{4}\right)$, Sulphuric acid $\left(\mathrm{H}_{2} \mathrm{SO}_{4}\right), 4$ aminothiophenol (4ATP), ethanol, potassium hexacyanoferrate (II) trihydrate and Potassium hexacyanoferrate (III) were purchased from Sigma Aldrich (Darmstadt, Germany). Carbon screen-printed electrodes (CSPE) were provided by Zimmer \& Peacock (Horten, Norway).

\subsection{Electrochemical Measurements}

The EmStat Pico Module potentiostat controlled using the PSTrace 5.8 computer software was employed for all cyclic voltammetry $(\mathrm{CV})$, electrochemical impedance spectroscopy (EIS), chronoamperometric electrodeposition and differential pulse voltammetry (DPV) experiments. The CSPE was used as a three-electrode cell system comprising a carbon working electrode (WE), a carbon counter electrode (CE) and an $\mathrm{Ag} / \mathrm{AgCl}$ reference electrode (RE). EIS measurements were made at $6 \mathrm{mV}$ ac amplitude in the frequency range of $5.0 \mathrm{mHz}$ to $50 \mathrm{kHz}$ and the equivalent circuit models were fitted using PSTrace software.

\subsection{Electrodeposition of Gold Nanoparticles on CSPE}

A modified method from the literature was employed [10], an aqueous solution containing $2 \mathrm{mM} \mathrm{HAuCl}_{4}$ and $0.5 \mathrm{M} \mathrm{H}_{2} \mathrm{SO}_{4}$ was used to cover the CSPE, a chronoamperometric method using a constant potential of $-0.25 \mathrm{~V}$ for $60 \mathrm{~s}$ was used to deposit gold nanoparticles on top of the CSPE, and the electrode was washed with abundant deionized water, left to dry at room temperature and identified as AuNP-CSPE.

\subsection{Modification of AuNP-CSPE Electrodes with 4-ATP}

A previously reported method was adapted [11], in a typical experiment, and the working electrode was covered with $10 \mu \mathrm{L}$ of $10 \mathrm{mM}$ 4-ATP solution in ethanol at room temperature $\left(22^{\circ} \mathrm{C}\right)$ for $15 \mathrm{~min}$. Nonspecifically adsorbed molecules were flushed off by 
careful rinsing with ethanol and deionized water. The electrode was dried under a stream of nitrogen and identified as $\mathrm{NH}_{2}$-AuNP-CSPE. The amine functionality in the electrode could be used later to form an amide bond [12] and immobilize the mouse monoclonal antibodies against the HA H1N1 protein.

\subsection{Testing of $m A b$ Specificity and Sensitivity}

The enzyme-linked immunosorbent assay (ELISA) was used for this purpose. The protocol used for this indirect sandwich ELISA assay was in accordance with the mAb provider [13].

\section{Results and Discussion}

\subsection{Electrodeposition of Gold Nanoparticles}

The CSPEs offered a reasonable potential window to study the redox reaction of the $\left[\mathrm{Fe}(\mathrm{CN})_{6}\right]^{3-/ 4-}$ system and showed a symmetric shape, and the distance between the oxidation and the reduction peaks was of $727 \mathrm{mV}$ (Figure 1); this value was much higher than the prediction of the Nerst equation for single electron transfer reactions and was attributed to a drop in potential due to the resistance of the carbon material [14]. When the CSPEs were modified with gold nanoparticles, the reversibility of the $\left[\mathrm{Fe}(\mathrm{CN})_{6}\right]^{3-/ 4-}$ redox system increased as the distance between the oxidation and reduction peaks was $280 \mathrm{mV}$ on the voltammogram; this was attributed to the increase in the surface area of the electrode and to the high conductivity of metallic gold nanoparticles.

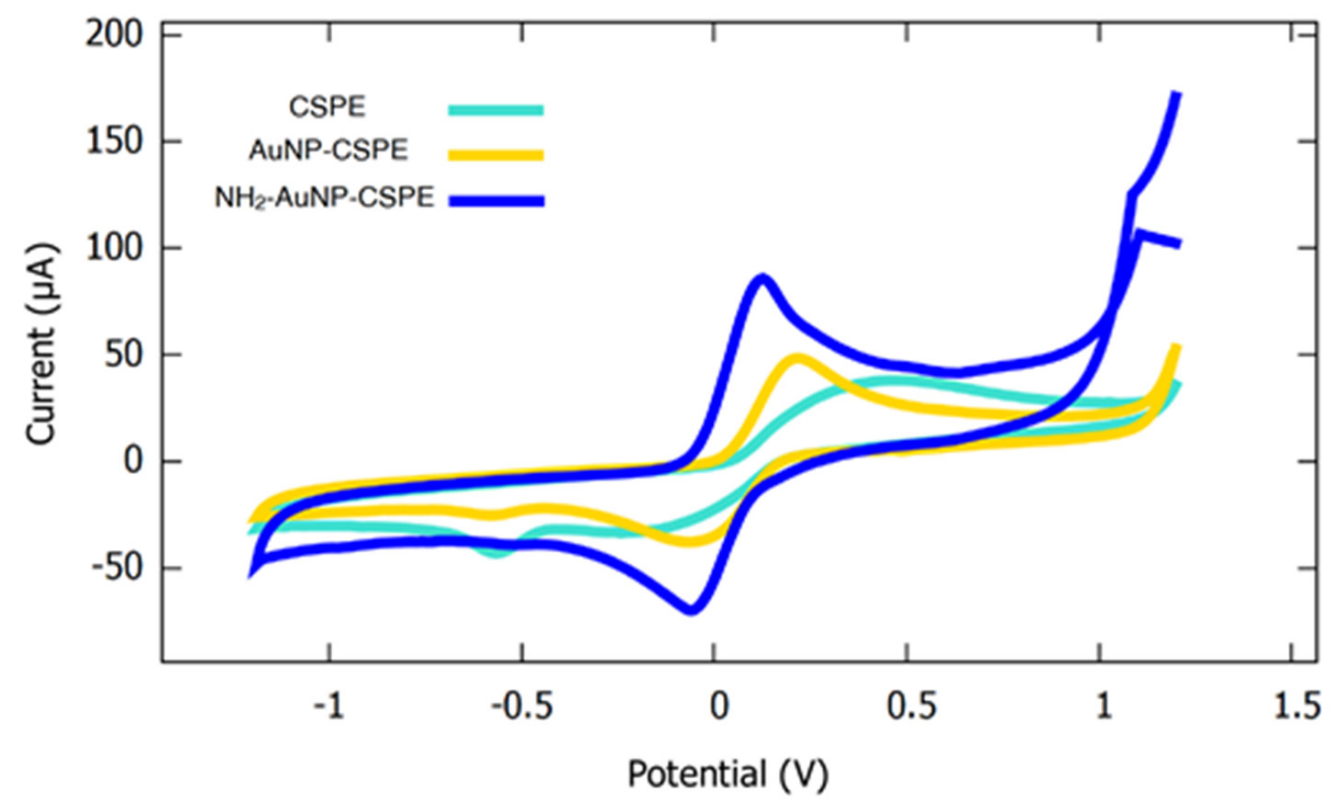

Figure 1. Cyclic voltammogram of CSPE, AuNP-CSPE and $\mathrm{NH}_{2}-\mathrm{NP}-\mathrm{CSPE}$ in the presence of $\left[\mathrm{Fe}(\mathrm{CN})_{6}\right]^{3-/ 4-}$ obtained at a scan rate of $100 \mathrm{mV} / \mathrm{s}$.

\subsection{Electrodeposition Length}

Further study into the gold electrodeposition process as a function of time (Figure 2) showed that longer reaction times than one minute do not increase either the current response of the electrode or the reversibility of the system. 


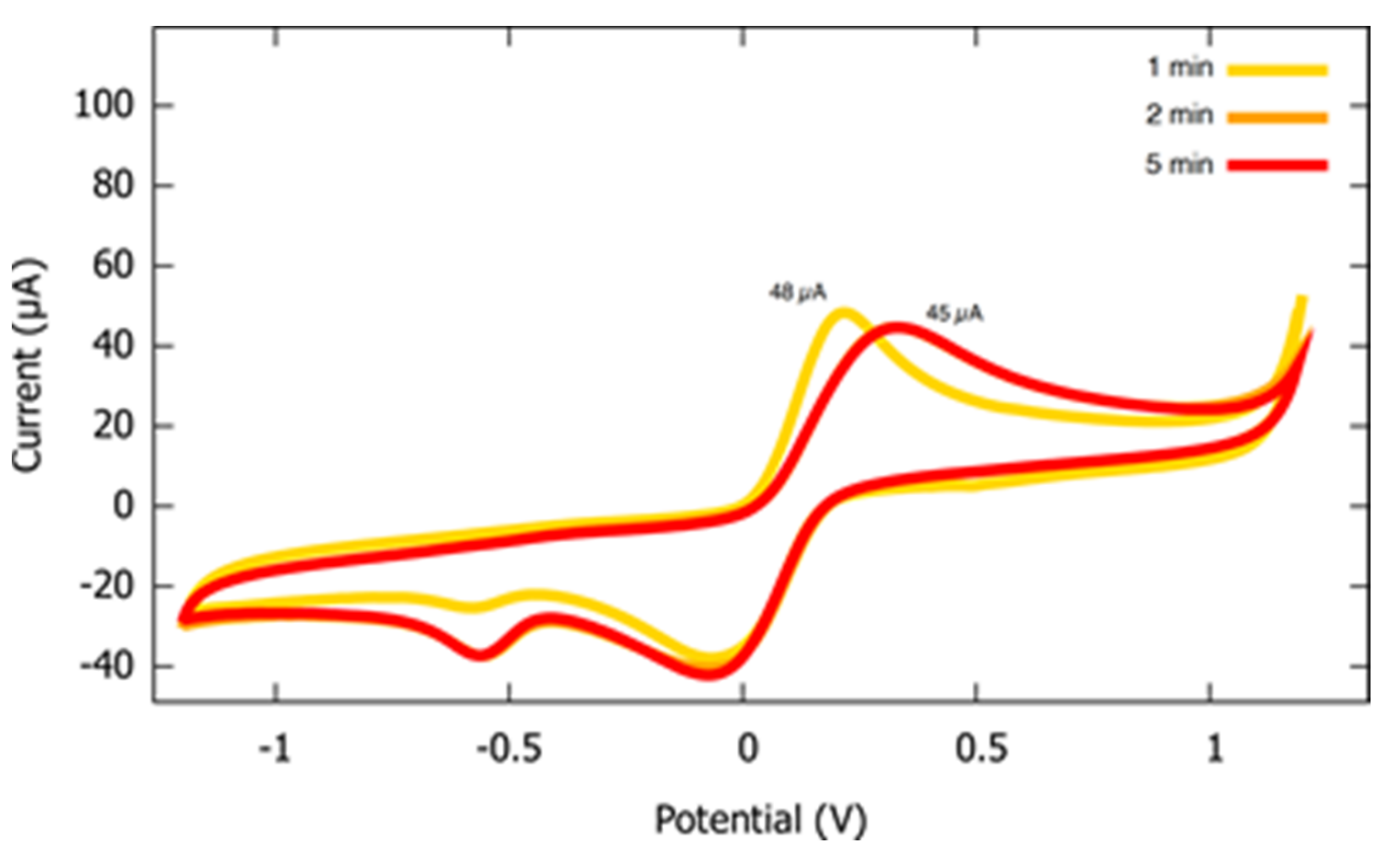

Figure 2. Cyclic voltammogram of modified AuNP-CSPEs using different electrodeposition times; the experiment was conducted in the presence of $\left[\mathrm{Fe}(\mathrm{CN})_{6}\right]^{3-/ 4-}$ at a scan rate of $100 \mathrm{mV} / \mathrm{s}$.

\subsection{Characterization of $\mathrm{NH}_{2}-\mathrm{AuNP}-\mathrm{CSPE}$}

The cyclic voltammogram of $\mathrm{NH}_{2}$-AuNP-CSPE showed promising results due to the functionalization of the nanoparticles with the 4-ATP linker molecule (Figure 1), as the reversibility of the system increased and the electron transfer process for the reduction and oxidation reactions of $\left[\mathrm{Fe}(\mathrm{CN})_{6}\right]^{3-/ 4-}$ was facilitated on these modified electrodes due to the $\pi$ delocalized system of the linker molecule. The electrochemical impedance spectroscopy tests indicated a decrease in impedance after the modification of the electrodes with gold nanoparticles and 4-ATP linker (Figure 3). The Nyquist plot of the bare CSPE can be fitted to an equivalent circuit for a simple electron-transfer reaction and $\mathrm{NH}_{2}$ AuNP-CSPE can be fitted to the classical Randles equivalent circuit comprising the ohmic resistance of the electrolyte solution $\left(R_{\Omega}\right)$ and the charge transfer resistance $\left(R_{C T}\right)$, in series with the Warburg impedance element (diffusion controlled impedance) and in parallel with a double layer capacitance $\left(\mathrm{C}_{\mathrm{DL}}\right)$ (Figure 4$)$. The modified $\mathrm{NH}_{2}$-AuNP-CSPE showed a significantly smaller $\mathrm{R}_{\mathrm{CT}}$ and is, therefore, highly conductive compared to the bare CSPE.

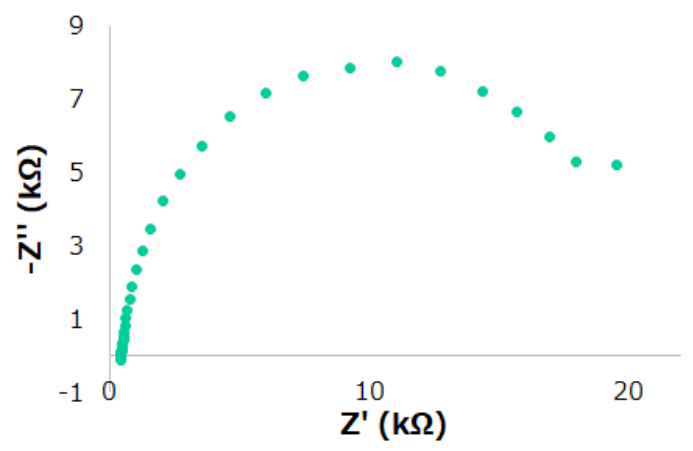

(A)

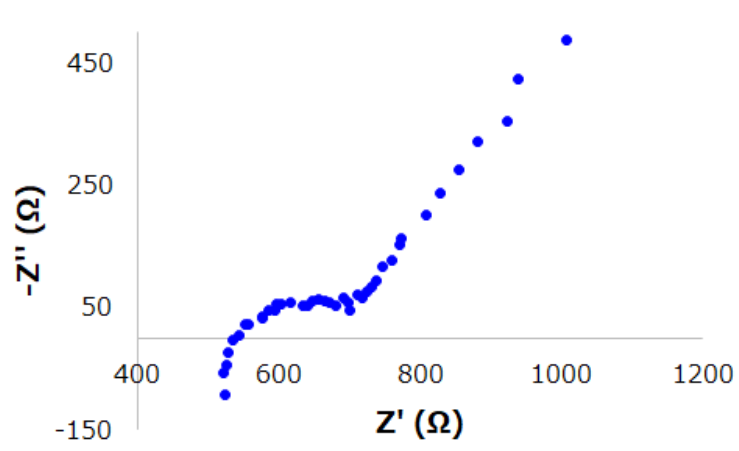

(B)

Figure 3. Nyquist plot of CSPE (A) and $\mathrm{NH}_{2}$-AuNP-CSPE (B) using the frequency range of $5.0 \mathrm{mHz}$ to $50 \mathrm{kHz}$. 


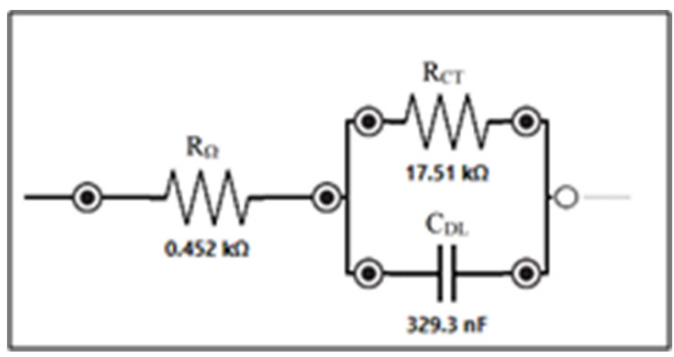

(A)

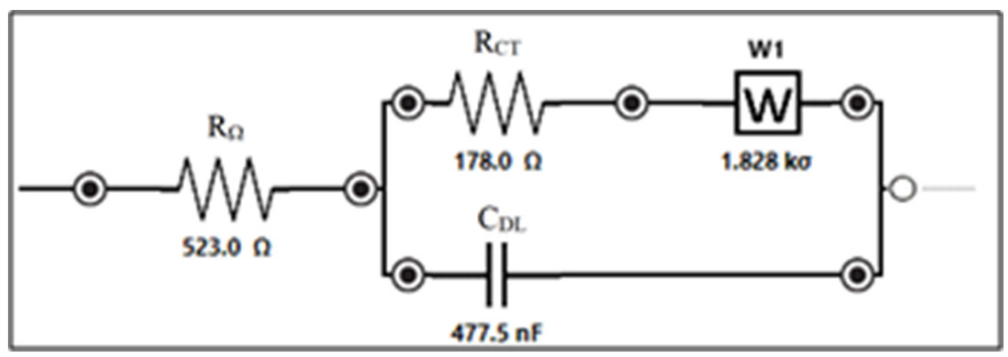

(B)

Figure 4. Fitting of CSPE to equivalent circuit for a simple electron transfer (A) and fitting of the $\mathrm{NH}_{2}$-AuNP-CSPE Randles equivalent circuit (B).

\subsection{Effect of the $\left[\mathrm{Fe}(\mathrm{CN})_{6}\right]^{3-/ 4-}$ Concentration}

The effect of the $\left[\mathrm{Fe}(\mathrm{CN})_{6}\right]^{3-/ 4-}$ concentration over the current response was evaluated by the means of CV and DPV (Figure 5), with a higher concentration of the electroactive species in the solution implying that more $\left[\mathrm{Fe}(\mathrm{CN})_{6}\right]^{3-/ 4}$ molecules could reach the surface of the $\mathrm{NH}_{2}$-AuNP-CSPE to undergo oxidation and reduction, respectively. In the experiment, higher current responses were observed at high concentrations of $\left[\mathrm{Fe}(\mathrm{CN})_{6}\right]^{3-/ 4}$. This experiment provided a visual basis for the expected effect on the final design of the biosensor, where the $\mathrm{NH}_{2}$-AuNP-CSPE is going to be coupled to monoclonal antibodies against the $\mathrm{H} 1$ protein and a blocking effect over $\left[\mathrm{Fe}(\mathrm{CN})_{6}\right]^{3-/ 4}$ (lowering the current response) could take place once the $\mathrm{H} 1$ protein is bound to the antibody-modified electrode.

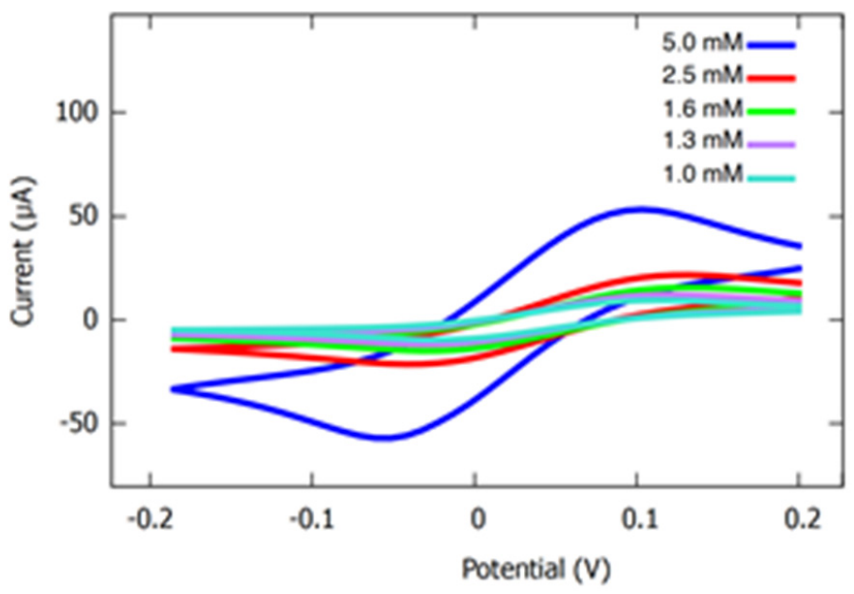

(A)

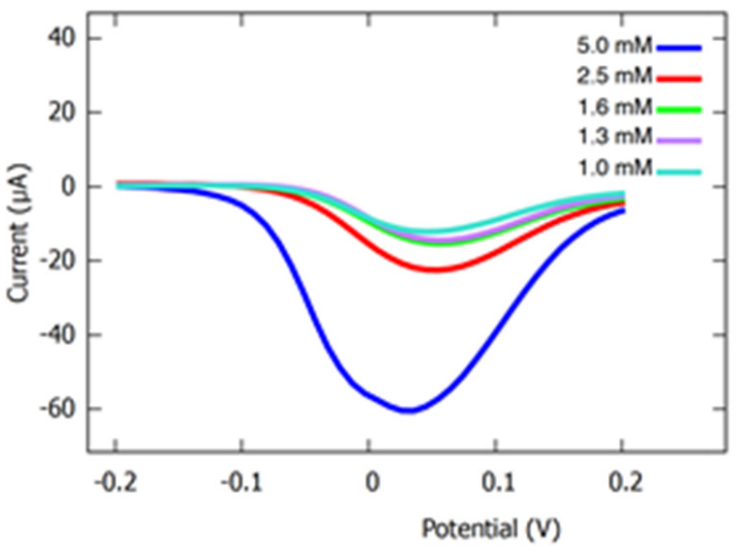

(B)

Figure 5. Cyclic voltammogram (A) and differential pulse voltammogram (B) for $\mathrm{NH}_{2}$-AuNP-CSPE as a function of the $\left[\mathrm{Fe}(\mathrm{CN})_{6}\right]^{3-/ 4-}$ concentration.

\section{5. $m A b$ Characterization}

To characterize the specificity of the monoclonal antibody targeting the $\mathrm{H} 1$ protein, an indirect sandwich ELISA was conducted. It was shown that the antibody can detect the H1 protein specifically (Figure 6). The approach was tested for different $\mathrm{H} 1$ concentrations and the lowest detectable concentration was $10 \mathrm{ng} / \mathrm{mL}$. 


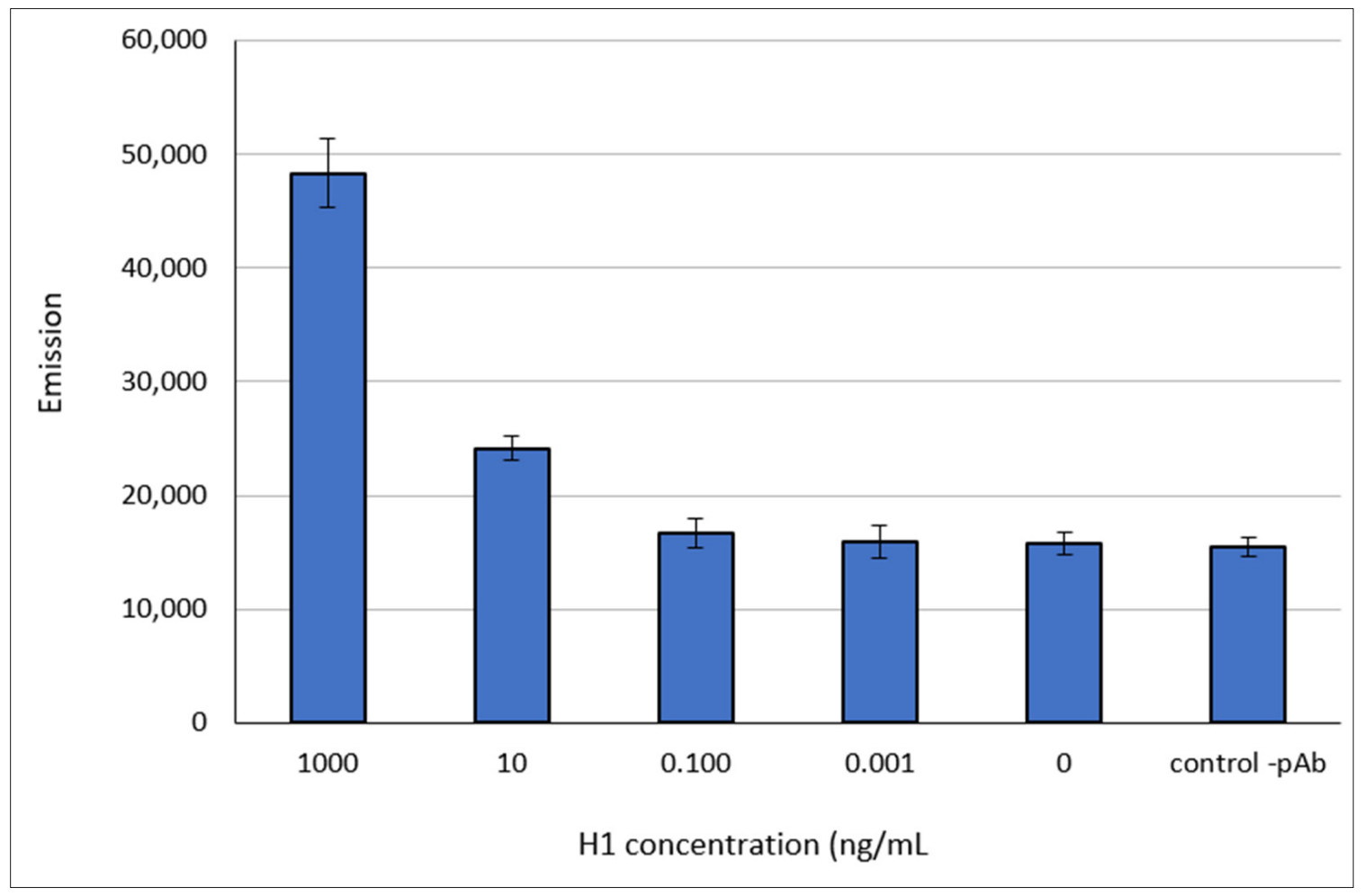

Figure 6. Indirect sandwich ELISA results using 1:500 dilution of $\mathrm{mAb}, 1: 1000$ dilution of $\mathrm{pAb}$ and different $\mathrm{H} 1$ concentrations as shown in the $x$ axis; the $y$ axis shows the emission measured after the addition of the secondary antibody. Experiments were conducted twice with replicates of 2-6.

\section{Conclusions}

Cost-effective CSPE were modified with gold nanoparticles and 4-ATP, and the electrodes were characterized by means of electrochemical methods in the presence of $\left[\mathrm{Fe}(\mathrm{CN})_{6}\right]^{3-/ 4-}$ complexes. The redox system $\left[\mathrm{Fe}(\mathrm{CN})_{6}\right]^{3-/ 4-}$ was found to be more reversible in the modified electrodes AuNP-CSPE and $\mathrm{NH}_{2}$-AuNP-CSPE than in the bare CSPE. The modified $\mathrm{NH}_{2}$-AuNP-CSPE showed a decrease in impedance compared to CSPE, indicating that the electron transfer process is more favorable in the modified electrode. With the indirect sandwich ELISA, it was shown that the monoclonal antibody specifically targets the HA H1N1 protein and can be further used in the biosensor setup. The amine functionality on the modified electrodes can be exploited to couple mouse monoclonal antibodies against the HA H1N1 protein in future work within this project. In addition to this, aims for future work include the detection of the HA H1N1 protein in artificial saliva using DPV, the establishment of a protocol using bovine serum albumin (BSA) to avoid non-specific binding, and the determination of the sensibility and detection limits of the biosensor.

Author Contributions: Conceptualization, data curation, formal analysis and visualization, C.T.-M., S.N., P.K., J.S. and V.L.; methodology, A.-R.A. and E.M.D.; software and validation, J.E., Y.L. and S.T.; investigation, I.J., M.L. (Maike Lüftner), K.M. and M.L. (Maria Lysandrou); resources, D.B.; writing-original draft preparation, C.T.-M., G.-V.G., P.K. and M.I.M.; writing-review and editing, C.T.-M. and P.K.; supervision, project administration and funding acquisition M.K.-M. and G.M. All authors have read and agreed to the published version of the manuscript.

Funding: This work was supported by the Disciplinary Domain of Medical and Pharmacy and Disciplinary Domain of Science and Technology at Uppsala University, Swedish Research Council under grant 2020-02258 and Swedish Institute's scholarship to C. Torres-Méndez.

Institutional Review Board Statement: Not applicable. 
Informed Consent Statement: Not applicable.

Data Availability Statement: All data are included herein and no data deposited in external repositories.

Acknowledgments: We are grateful to SensUs organization for all the support. We are also grateful to Quentin Palomar-Marchand for the technical advice provided for the electrochemical measurements and Zimmer \& Peacock for providing the carbon screen-printed electrodes used in this study.

Conflicts of Interest: The authors declare no competing interest.

\section{References}

1. Patel, M.; Dennis, A.; Flutter, C.; Khan, Z. Pandemic (H1N1) 2009 influenza. Br. J. Anaesth. 2010, 104, 128-142. [CrossRef] [PubMed]

2. 2009 H1N1 Pandemic. Centers for Disease Control and Prevention. Available online: https://www.cdc.gov / flu/pandemicresources/2009-h1n1-pandemic.html (accessed on 11 June 2019).

3. Krammer, F.; Smith, G.J.D.; Fouchier, R.A.M.; Peiris, M.; Kedzierska, K.; Doherty, P.C.; Palese, P.; Shaw, M.L.; Treanor, J.; Webster R.G.; et al. Influenza. Nature Reviews. Dis. Primers 2018, 4, 3. [CrossRef] [PubMed]

4. Jilani, T.N.; Jamil, R.T.; Siddiqui, A.H. H1N1 Influenza. In StatPearls; StatPearls Publishing: Treasure Island, FL, USA, 2021.

5. Sriwilaijaroen, N.; Suzuki, Y. Molecular basis of the structure and function of H1 hemagglutinin of influenza virus. Proc. Jpn. Acad. Ser. B 2012, 88, 226-249. [CrossRef] [PubMed]

6. Ravina, R.; Dalal, A.; Mohan, H.; Prasad, M.; Pundir, C. Detection methods for influenza A H1N1 virus with special reference to biosensors: A review. Biosci. Rep. 2020, 40, BSR20193852. [CrossRef] [PubMed]

7. Antibodies Use in Biosensors. Available online: News-Medical.Net (accessed on 20 January 2021).

8. Sharma, S.; Byrne, H.; O'Kennedy, R.J. Antibodies and antibody-derived analytical biosensors. Essays Biochem. 2016, 60, 9-18. [PubMed]

9. Chambers, J.P.; Arulanandam, B.P.; Matta, L.L.; Weis, A.; Valdes, J.J. Biosensor recognition elements. Curr. Issues Mol. Biol. 2008, 10, 1-12. [PubMed]

10. Wang, Y.C.; Cokeliler, D.; Gunasekaran, S. Reduced graphene oxide/carbon nanotube/gold nanopar-ticles nanocomposite functionalized screen-printed electrode for sensitive electrochemical detection of endocrine disruptor bisphenol A. Electroanalysis 2015, 27, 2527-2536. [CrossRef]

11. Valerio, E.; Abrantes, L.M.; Viana, A.S. 4-Aminothiophenol Self-Assembled Monolayer for the De-velopment of a DNA Biosensor Aiming the Detection of Cylindrospermopsin Producing Cyanobacteria. Electro-Anal. Int. J. Devoted Fundam. Pract. Asp. Electroanal. 2008, 20, 2467-2474.

12. Rezki, M.; Septiani, N.L.W.; Iqbal, M.; Harimurti, S.; Sambegoro, P.; Adhika, D.R.; Yuliarto, B. Amine-functionalized Cu-MOF Nanospheres towards Label-free Hepatitis B Surface Antigen Electrochemical Immunosensors. J. Mater. Chem. B 2021, 9 , 5711-5721. [CrossRef] [PubMed]

13. Sandwich ELISA Protocol ISino Biological. (n.d.) Available online: https://www.sinobiological.com/category/sandwich-elisaprotocol (accessed on 13 June 2021)

14. Damiati, S.; Haslam, C.; Sopstad, S.; Peacock, M.; Whitley, T.; Davey, P.; Awan, S. Sensitivity Comparison of Macro- and MicroElectrochemical Biosensors for Human Chorionic Gonadotropin (hCG) Biomarker Detection. IEEE Access 2019, 7, 94048-94058. [CrossRef] 